\title{
Angles
}

New Perspectives on the Anglophone World

$6 \mid 2018$

Experimental Art

\section{Experimental Fiction, Or What Is a Novel and How Do I Know?}

\section{Ralph M. Berry}

\section{Q OpenEdition \\ 1 Journals}

\section{Electronic version}

URL: https://journals.openedition.org/angles/986

DOI: 10.4000/angles.986

ISSN: 2274-2042

\section{Publisher}

Société des Anglicistes de l'Enseignement Supérieur

\section{Electronic reference}

Ralph M. Berry, "Experimental Fiction, Or What Is a Novel and How Do I Know?", Angles [Online], 6। 2018, Online since 01 April 2018, connection on 07 June 2022. URL: http://journals.openedition.org/ angles/986 ; DOI: https://doi.org/10.4000/angles.986

This text was automatically generated on 7 June 2022

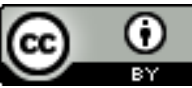

Angles est mise à disposition selon les termes de la Licence Creative Commons Attribution 4.0 International. 


\title{
Experimental Fiction, Or What Is a Novel and How Do I Know?
}

\author{
Ralph M. Berry
}

Some years ago while preparing for class, I needed to quote Wittgenstein but did not have my current copy of Philosophical Investigations (2009) at my office (henceforth abbreviated as PI). As a result, I found myself paging through the old, marked-up paperback I had studied as a graduate student. The passage I sought was $\$ 283$, which begins with the question: "What gives us so much as the idea that beings, things can feel?" Glancing at my marginal notes, I was surprised to discover that I had originally taken the passage in a sense exactly opposite my present understanding. That is, I had taken Wittgenstein's question rhetorically, as a challenge to our confidence that other creatures have feelings. It was as though Wittgenstein himself doubted that horses and dogs can really suffer. Such an interpretation now struck me as preposterous. It flew in the face of Wittgenstein's insistence in PI $\$ 303$ that doubting pain in any real situation is immensely difficult, his insinuation in PI \$245 that trying to know pain better than its outward manifestation has something outlandish about it, and his statement in PI \$250 that it makes no sense to say a dog's pain is only a simulation. Responding to the feelings of others is what Wittgenstein calls a "form of life," a way of interacting in which human beings agree. For him, questioning forms of life is futile. It was as though, having failed to take Wittgenstein's question literally - that is, as a frank inquiry about our bond with others - I had gotten his philosophy exactly backwards.

2 So my question is this: why would Wittgenstein ask his question in this form? That is, the phrase "so much as the idea" is ordinarily rhetorical, is normally used to express suspicion of an idea. Its implication is that some conventional belief is dubious, with the accompanying insinuation that those accepting it have been uncritical or naive. My earlier interpretation, even if mistaken, was hardly idiosyncratic. So, if Wittgenstein did not intend to question our forms of life, why would he use a form of expression that in both German and English seems to invite misreading, a form that Wittgenstein actually does use rhetorically in his very next section? "How could one so much as get the idea of ascribing a sensation to a thing?" he asks in \$284, and then retorts: “One 
might as well ascribe it to a number!" The derision in these sentences seems unmistakable. I wouldn't even know how to take them literally. I mean, if you ask me, "What gives you so much as the idea I care?" I am not likely to think you are making a frank inquiry.

3 I start with this example from Wittgenstein because, when thinking about experimental fiction at the present time, one does not know where to start. No novelist or movement or body of work provides the kind of central or orienting position, at least among Anglophone writers and critics, that Joyce, Woolf, Faulkner, and Beckett provided fifty years ago, and I do not just mean that beginning with William Gass's The Tunnel or Theresa Cha's Dictée or George Perec's Life: A User's Manual will seem controversial. I mean that it is likely to seem arbitrary, as though one had merely universalized one's own subject position or feelings. In saying that a few mostly white, mostly male, mostly Irish modernists once provided an "orienting position," I have in mind something more than that they possessed cultural authority and canonical status, although I do not want to minimize these crucial facts. However, I am also referring to a position already staked out at their works' first appearance, a position not reducible to their later institutional recognition and that differentiated them from near contemporaries like E.M. Forster, Edith Wharton, Graham Greene, and Theodore Dreiser. I would describe it this way: early modernist experimental novels presented themselves, not just as formal innovations or challenges to realist conventions, but as disclosures of what a novel is, of the novel as such. That is, for a reader of Gertrude Stein's Melanctha or Joyce's Portrait of the Artist or Proust's Swann's Way, it became necessary to reconsider, not only what the activities of reading and writing fiction might mean at present or in the future, but also what these activities had meant at any time, even in the best known works of the past. That people accepted these modernist experiments as novels at all thus seemed more consequential than whether reviewers extolled them as masterpieces or dismissed them as failures. The question that their acceptance forced, assuming one regarded Eliot's Middlemarch and Flaubert's Madame Bovary as classics of the genre, was how the same concept could apply to such different examples. Either one ruled out these experiments by definition, it seemed, thus fixing a limit on one's concept - something earlier novelists and their readers had rarely needed to do - or one acknowledged that novels apparently never had been what, prior to these works, everyone believed them to be.

What I mean by staking out an orienting position becomes clearer, I think, if we compare these early $20^{\text {th }}$-century novelistic experiments with modernist painting. For the turnof-the-century curators, critics, and painters aligned with Impressionism, the paintings of Cézanne, Van Gogh, and les Fauves did not look particularly innovative. Despite its break with Courbet's realism, Monet's Impressionism was still recognizable as a new, subjective inflection of the representational aims of earlier art, something British art historian Roger Fry showed (Fry 1996a) but interpreting Cézanne's or Van Gogh's painting as Neo-Impressionist - that is, as a new, subjective inflection of Impressionism itself - discounted their work altogether, making it the symptom of an idiosyncratic or aberrant psychology. Part of what made Fry's advocacy of modernist painting so controversial was his frank recognition that, for Cézanne and Van Gogh to count as artists, the subject of Western art history would have to be reconceived. According to Fry, what Post-Impressionist painters had discovered was "the visual language of the imagination", an abstract grammar of shapes and colors, immanent in all classic art, but which, despite changing conventions of representation, spoke "directly to the 
spirit" (Fry 1996b: 100, 106). Even for those who remained unconvinced, Fry's account raised the stakes of aesthetic discussion unprecedentedly high. Monet might be criticized for obscuring the reality Courbet had made vivid, just as Henry James was often faulted for submerging action in the vagaries of consciousness, but such disagreements did not stake the very concept of painting or fiction. However, if one took Fry seriously, then the risk of failing to appreciate Cézanne's achievement was that one might fail to know what made painting an art. It was as though modernist works had fused example and concept, practice and theory, present and past. This fusion, or the possibility of it, was what inspired critics like Cleanth Brooks, not just to concede, but to assert that he was reading Shakespeare and Milton "as one has learned to read [...] the moderns" (Brooks 1947: 193), and when Viktor Shklovsky called Tristram Shandy "the most typical novel in world literature" (Shklovsky 1965: 57), he, too, was reordering literary history in accord with contemporary experimentation.

5 All of this may sound both familiar and wrong. My claim has been that what made novels like Joyce's Ulysses or Faulkner's The Sound and the Fury or Woolf's To the Lighthouse different from novels at other times, both before and since, was neither their innovations of form and content nor their challenges to norms of representational fidelity, but their revelation of something about novels at all times, something about the human form of life to which the reading and writing of novels is integral. It was only because modernist experiments laid bare these lived conditions of our concepts, or seemed to, that formalist critics like Fry, Brooks, and Shklovsky, to name just three, found it reasonable to construct a systematic criticism on their basis. However, it remains debatable whether the effect of such disclosures, when viewed in the light of subsequent history, has been more orienting than confusing. I will explain what I mean with an example of modernist fiction's raised stakes.

In "Mr. Bennett and Mrs. Brown," Virginia Woolf maintained that the novelists of her generation experimented, not out of rebelliousness or a desire for originality, but because, at the time they began writing, "there was no English novelist living from whom they could learn their business" (Woolf 1993: 240). Unlike the classic novelists Woolf's examples are Jane Austen and Laurence Sterne - turn-of-the-century novelists like Arnold Bennett substituted social circumstances, economic conditions, and other conventional markers of identity for what novelists find "permanently interesting," something Woolf repeatedly calls "character in itself" (Woolf 1993: 235, 236, 240). In her essay, this quality, immanent in all classic fiction, is what orients novelists and their readers in the way that Fry's "visual language" of shapes and colors is supposed to inform painting. It makes the novelist's art what it is. However, when Woolf tries to explain what she means by "character in itself," she finds herself in a position not so different from Bennett's. Not only is she unable to abstract this quality from its conventional associations, but even when she tries to tell a story, hoping to exemplify it, her embodiment of human character, Mrs. Brown, recedes into an "atmosphere," an "impression," an incommunicable "vision" (Woolf 1993: 238, 245). Woolf's nearest approach comes with saying that what makes any character outlive convention is not its lifelikeness, but rather its "power to make you think not merely of itself, but of all sorts of things through its eyes" (Woolf 1993: 239). The idea seems to be that, "in itself," character is distinct from the markers by which it is identified. Experiencing it is less like recognizing someone than like experiencing her experiencing. The emphasis falls, 
not on what the other sees or thinks or feels or even how differently, but on experiencing as she experiences, from her position, in her time.

7 Apparently, Woolf thinks that what makes the novel confusing, especially for beginning readers and writers, is not that this source of its interest changes. Although famously announcing that human character changed in the month and year that Roger Fry introduced modernist painting to the London public, Woolf identifies her exemplar of character, Mrs. Brown, not with her generation's distinctive viewpoint, but with the timeless reality that she claims the novel as a form evolved to express. "Mrs. Brown is eternal," she declares, "Mrs. Brown is human nature, Mrs. Brown changes only on the surface" (Woolf 1993: 243). Nor does the problem seem to be that character is metaphysically other, essentially multiple, or even particularly difficult to know. On the contrary, Woolf stipulates that no one could long survive in the world without "a good deal of skill in character reading" (Woolf 1993: 235) and insists that her audience is as intimately acquainted with it as she. In fact, it is precisely the familiarity of "character in itself" that seems confusing. Noting that in the course of daily life everyone has experiences of character as vivid as Woolf's experience of Mrs. Brown, Woolf chides her audience for reading so uncritically: "In your modesty you seem to consider that writers [...] know more of Mrs. Brown than you do," she declares. "Never was there a more fatal mistake" (Woolf 1993: 248). Again, the stakes seem very high. Woolf's implication is that all readers should be as uncompromising as her own generation, should accept no substitute for what makes works like Pride and Prejudice and Tristram Shandy permanently interesting. And if, as a result, we find ourselves in her generation's predicament, if no character, not even Mrs. Brown, adequately represents character "in itself," that is, if examples and concepts do not fuse, then no novel or novelist provides an orienting position. The starting point for knowing what a novel is has shrunk to the size of the individual subject. It is as though every life were an experiment.

8 I have tried to bring out a potential, if not quite for solipsism, then for something like radical individuation in the tendency of early $20^{\text {th }}$-century experimental novels both to force the question of what a novel is and to present themselves as answers, and my argument is that we cannot make sense of the novel's subsequent history without appreciating this potential. It is the success, not the failure, of works like To the Lighthouse that assigning an orienting position to experimental novels or novelists today appears arbitrary. However, I must first return to Wittgenstein's question, "What gives us so much as the idea that beings, things can feel?" for it demonstrates how critical for our knowledge of any concept such experimentation is. If other readers are as impressed as I originally was with the difficulty of answering this question, then part of what seems impressive is that the difficulty results from no lack of knowledge of others' feelings. This paradox - that we find ourselves unable to answer questions to which it seems everyone must know the answer - recurs throughout Wittgenstein's philosophy. In truth, it seems as unclear in Philosophical Investigations as in "Mr. Bennett and Mrs. Brown" how we could be ignorant of what others feel, since in both works our attunement to those around us appears so deep and pervasive. Like Woolf, Wittgenstein believes that we are frequently aware of someone else's sensations, that an acquaintance's mood can affect us powerfully, and that, seated on a jet or train or bus, we may have difficulty not knowing more about what some stranger feels than we want to. In Wittgenstein's later philosophy, all of our concepts depend on shared forms of expression and response similar to those Roger Fry believed modernist painting had 
disclosed, forms so integral to our lives that, were we unacquainted with them, we would not be able to learn what they are.

However, despite our familiarity with these forms, it appears far from clear in Philosophical Investigations that we know them. One reason for doubt is that, when questioning any concept, we regularly confuse them with some picture (bild) or explanatory model inherited with our language (PI \$115), and if we try to abstract the form from the words (\$90-91, §120), or from the picture with which past usage has associated our words, we easily become disoriented (\$123), as though our native language were foreign to us (\$116). Although this disorientation discloses a gap between what everyone knows and what anyone can say about it, Wittgenstein does not think that an accurate representation of our shared patterns of expression and response would close the gap. On the contrary, this representation, or its lack, is itself part of our confusing picture. In explaining the kind of representation that he thinks would, if not close the gap, then make it disappear, the kind he calls "surveyable" or "perspicuous" (übersichtliche, [PI \$122]), Wittgenstein describes how we experience such a gap:

Here the fundamental fact is that we lay down rules, a technique, for playing a game, and that then, when we follow the rules, things don't turn out as we had assumed. So that we are, as it were, entangled in our own rules. (PI \$125)

Wittgenstein's point here is not that these rules are the wrong rules; even less is it that there really are no rules, no collective regularities of expression and response with which, when correctly applied, our concepts conform. His point is more nearly that having a concept of something, knowing what feeling is, means knowing examples of it, knowing feelings, not knowing rules, forms, conventions, definitions, etc. (PI \$69, §208). And if this tautology is Wittgenstein's response to the question, "What gives us so much as the idea that beings, things can feel?", then how does the philosophical problem of feeling - or of any other concept - arise in the first place? Or as Wittgenstein puts it: "This entanglement in our rules is what we want to understand: that is, to survey" (übersehen [PI \$125]).

11 It has often been remarked that the experimental fiction of the fifties, sixties, and seventies, especially in the U.S., but also in Ireland, Latin America, France, Italy, England, and elsewhere, seemed almost written against itself, creating philosophical and narrative problems that it then tried, with unclear success, to overcome. Like the novelists of Woolf's generation, the post-WWII writers of anti-novels, metafiction, the nouveau roman, early magical realism, and Oulipian potential literature, all struggled against what they considered widely-disseminated misrepresentations of their art, but the novels with which they contrasted their works were not only those of the previous generation, that is, the - by now classic - experiments of early modernism. Rather, their struggle was also against contemporary and near-contemporary novelists who wrote as though modernism had never occurred. To the Post-war experimenters, writing a novel meant, among other things, doing what Woolf, Stein, Joyce, Kafka, and Proust had done: laying bare conditions realism had obscured, abstracting human interests from their conventional displacements, disclosing what fiction is, what reading and writing means. However, their on-going commitment to experimentation exposed a paradox. What exactly had the modernists disclosed? Was it, as Fry claimed, certain forms immanent in all classic works, forms that made possible one human's representation of another and on which the significance of stories at any time depended, or had modernism demonstrated the limits of such forms? That is, had novels like Stein's The Making of Americans and Joyce's Finnegans Wake shown that the 
collective regularities of expression and response were always inadequate, that fiction, when it achieved what classic novels had achieved, was reducible to nothing preexisting? Writing in the early seventies, Italo Calvino described literary experimentation as inherently divided, expressing both a desire for autonomy, for literature's existence as "merely the permutation of a finite set of elements and functions," and also a desire to transcend these elements and functions, to "escape from the confines of language" (Federman 1975: 76-7). Woolf's pursuit of character "in itself" can be understood as an expression of either desire or both. And if Calvino was right, then the postwar experimenters faced a choice: either they could restrict themselves to playing with the forms modernism had already disclosed - forms that, although timeless, seemed finite in number - or they could attempt a self-overcoming so absolute, so singular, that the novel as a concept would cease to exist.

Surveying the literary experiments of the fifties, sixties, and seventies, I am struck by how often the insistence on a novel's construction from definite recurrent forms accompanies the attempt to differentiate it from everything pre-existing, determinate, or separately knowable. In the most blatant version, these two, seemingly opposed tendencies converge in a novel's dispelling of its own representational illusion, as when Humbert tells us in the twenty-ninth section of Part Two of Nabokov's Lolita (1970), "Then I pulled out my automatic - I mean, this is the kind of fool thing a reader might suppose I did;" (282) or when at the end of Beckett's Molloy (1955) Jacques Moran disavows his narrative's beginning; or when in Fowles's The French Lieutenant's Woman (1969) the narrator remarks, "The story I am telling is all imagination. These characters I create never existed outside my own mind" (80). An effect of such disillusionments is to abstract the activity of narrating from the action narrated, locating the novel as such, if not in the words we are reading, then just where seems impossible to say. In the writings of Borges, Calvino, Beckett, Christine Brooke-Rose, B. S. Johnson, Ishmael Reed, William Gass, Harry Matthews, Clarence Major, Nathalie Sarraute, Alain RobbeGrillet, and Monique Wittig, to name only a few, this irreducibility of novels to determinate representation seems, not just compatible with, but paradoxically dependent on, generic conventions, plot types, and stock characters sufficiently determinate to be themselves represented. When at the beginning of John Barth's story "Lost in the Funhouse," (1988) we are told how all story beginnings function, or when in Borges' "The Library of Babel" (1962) we learn of the one book that comprehends all the others, or when we discover in Gilbert Sorrentino's Mulligan's Stew (1996) the characters and settings of countless earlier novels, the novel as such seems, if anything, simply this example in my hand. Such singularity is one version, I believe, of what novelistic experiments, from early modernism to the present, want. That words are different from meanings, the announced theme of William Gass's novel Willie Master's Lonesome Wife (1971), is not for novelists a linguistic theory, philosophical thesis, or empirical fact. It is a narrative predicament, and its resolution depends, not on readers accepting this difference, or even making sense of it, but on words becoming as immediately interesting as pleas for help or cries of pain. Only when the word "novel" acknowledges what I am doing now, does Gass's novel - or any novel - do more than create confusion by saying, "These words are all I am" (not paginated).

To those for whom writing in the Post-war period meant, not just producing a new example of a widely-applied concept, but discovering what novels are, what a word like "novel" is doing, such singular achievements seemed the end of orienting positions. No novice writer or reader could learn her business from their example; nothing followed 
from them but themselves. However, as Calvino's description suggests, it was far from clear that this kind of transcendence was all the Post-war experimenters wanted. Even when the concept of a novel completely vanished into these self-identities, a question remained whether they had really established a limit on all pre-existing forms or merely disclosed a gap between what every novelist knew and what any novel could say about it. In fictions from the sixties such as Donald Barthelme's "Marie, Marie, Hold on Tight" (1961), Clarice Lispector's The Passion According to G. H. (2012), Thomas Pynchon's The Crying of Lot 49 (2006), or Ronald Sukenick's "The Death of the Novel" (2003), a philosophical problem of meaning comprised the narrative predicament, but rather than resolve it, interpreting these works as representations of representations only replicated the predicament, transferring to the reader responsibility for the problem.

In Sukenick's novella, a question about experimentation's meaning remained not just because, when announcing the death of the omniscient author, the fictional author, Ron, presumes to omniscience, nor even because he feels inspired to this selfovercoming by a student stroking his thigh underneath the seminar table. It remained because, when Ron tries to differentiate his writing from all pre-existing forms, his words are appropriated by the character Neal, a tormented war-protestor who, between the narrated action and the act of narrating it, throws himself off a bridge. Neal rails against the confines of language, despising all the unquestioning compromises that substitute for reality and pleading with Ron to "give me something that makes life worth living" (48). Both the fictional author and Neal, the fictional reader, seem to believe that, when satisfying answers come to an end, actions are what count, or in Ron's words, "Reality doesn't exist....There is only reading and writing, which are things we do" (41). However, nothing Ron can say, not even about the "things we do," counts for Neal, or not enough to make life worth living. If this pervasive unreality, which feels to Neal worse than death, is not to confuse what Sukenick's reader makes of it, reading must differentiate Neal's refusal of life from Ron's refusal to represent it, accepting no substitute for what is permanently interesting and closing the gap between action and narration, example and concept, present and past. This demand raises the stakes of both writing and reading as high as life itself, but without questioning to no end, how is anyone to discover what the word "novel" means?

When taken rhetorically, as a challenge to our concept of feeling, Wittgenstein's question in PI §283, "What gives us so much as the idea that beings, things can feel?", conjures a picture of human relations. In it, a gap separates what human beings know from the pain, fear, desire, or rage of others, both human and non-human. What bridges this gap are the regularities of expression and response shared by the members of any sociological or biological group. Experiencing another's experiencing, according to this picture, is responding in accord with the forms of one's own group to another's forms of expression. Regardless how immediate the experience, these shared forms mediate it, and if abstracted or represented separately, they will expose the gap. Anytime we question our concepts, this picture is apt to confuse us, substituting for or displacing the life we share with an indefinitely vast and diverse array of others, but not because it inaccurately represents human relations. On the contrary, it precisely depicts the distance between remorse and words of remorse, between any individual's mood and his or her demeanor, and between all present suffering and the account a sufferer gives of it later, and it gives a perceptible form to the potential for disaster of immediate, heartfelt responses to the misery of other groups. Wherever our collective and individual experience with these gaps has not proven comic or embarrassing, it has 
usually proven painful, leaving its impression on our bodies, minds, language, and social institutions. When, in the absence of any context suggesting derision or irony, we hear Wittgenstein insinuating in PI \$283 that we have been uncritical, we are responding to these individual and collective experiences of the gap and expressing how they have made us feel.

There is something that, until we hear Wittgenstein's question literally, we will have difficulty knowing, but the surprise of Wittgenstein's response to the question, a response running throughout the section of Philosophical Investigations (\$243 - \$315) dubbed "the private language argument" but concentrated in \$284 through \$287, is that what the question's rhetorical inflection makes difficult to know are not the feelings of others. On the contrary, all the examples in \$284 through \$287 presuppose this knowledge. That a wriggling fly vivifies my imagination as stones and numbers do not (\$284), that my relation to another's facial expression is hardly less direct than my relation to my own (\$285), that I respond to an injured person differently than to a damaged body part (\$286), that my pity tends to dispel my doubt (\$287), are just irrelevant psychological curiosities, not responses to the question in $\$ 283$ at all, unless I know in such circumstances that the concept of feeling is the issue. Apparently, my uncertainty, when it comes to applying this concept, whether there is really much difference between a fly and a stone does not mean that, when it comes to applying it, I do not know the difference between a fly and a stone. In fact, it is hard to imagine any difference I know better. As Wittgenstein says, "All our reactions are different" (\$284). If I nevertheless question it, if I continue to experiment with my application of this concept, inflecting PI \$283 ironically and opening a gap between words and feelings, then what I have taken for a representation, this picture of human relations, becomes my own doing. I am trying to find out something I cannot find out while acting in accord with my group. It is what feels so different anytime I hear Wittgenstein's question as a frank inquiry. And assuming that, even in the absence of satisfying answers, my questioning to no end is not just uncritical conformity, assuming I must know what I am doing, then there seems an obvious point: I experiment with how I express my feelings and question the forms in which I respond to the feelings of others because, otherwise, I will never know what it means to have a concept of feeling, to know what feeling is.

The accepted term among literary critics for writing like Wittgenstein's in PI $\$ 283$ is "performative." Such writing differs from representation in the way that action differs from the imitation of action and also in the way that any act of narrating differs from its resulting narrative of actions. Although in the absence of starting points and orienting positions what counts as experimental fiction will remain indefinite, I believe that the most satisfying experiments of the last three decades have been developments of performative writing, and, in closing, I want briefly to mention three, all written in the U.S. since the early nineties. They are Carole Maso's AVA (2002), Steve Tomasula's VAS (2004), and David Markson's Vanishing Point (2004). In these three works, the predicament in the novel is also the predicament of the novel, where that means the concept is implicated in the example, creating a problem for reading and writing that is overcome only by seeing what a novel is, what reading and writing fiction means. And, in all three, this predicament entails a gap separating the action from the narration. What is presently happening and how it is to be presented is itself the predicament. In Tomasula's VAS, this gap appears as an action that, from the start, the fictional author, Square, has already decided to perform, and the written consent to this action that he 
withholds. What creates their separation is the action's seeming implication in a story of violence, one written into nature and culture, which Square, the book VAS, Tomasula, and the reader all know is not merely fiction. In Maso's AVA, by contrast, the gap is between Ava's life as itself an action, one which, to be complete, needs more time, and her life as a story, occurring to her and us, if at all, only in a moment. Ava's predicament is that, having lived her first thirty-nine years as a perpetual beginning, as unlike anything she has experienced before, she is left feeling - along with Maso and the reader - that her end is premature. Finally, in Markson's novel the predicaments in and of the novel seem almost indistinguishable, amounting to little more than the fictional author's difficulties arranging the notes we read. Because the notes comprise roughly two-thousand examples of misrecognition and obtuseness, examples in which writers and artists figure prominently, we seem to confront, if not solipsism, than sheer arbitrariness when we read, "Author is pretty sure that most of [the notes] are basically in the sequence he wants" (Markson 2004: 8).

Although a gap between the action and its narration (between what is known and what can be said about it) seems implicit in any novel, constituting interests intrinsic to the genre, in Maso's, Tomasula's, and Markson's novels, this gap takes on a material form. In AVA and Vanishing Point, it appears as a uniform white space separating the individual fragments, while appearing in VAS as the lovely but erratic layout that eliminates the established indicators of textual continuity. In Markson's case, only the page numbering and periodic references to the fictional author provide any basis, external to the fragments' content, for supposing that our movement over the white space is oriented to more than an accidental beginning or end. The same seems true of Maso's novel, with the exception that no fictional author is present and the fragments have been divided into three sequential sections, "Morning," "Afternoon," and "Night." However, given both the randomness of Ava's memories and their tendency to recur in any section, searching for evidence of chronological development seems futile. In Tomasula's work, by contrast, the more or less conventional representation of Square's domestic conflict seems to establish a beginning and end unproblematically, but in the three-hundred intervening pages the action and its narration seem as discontinuous as in Markson and Maso. Not only are the pages of VAS inconsistently numbered, but with the continuity of speaker, topic, and time independent of the layout, although we may admire each page as we admire a painting or photograph, a passage's location in the printed text can mean nothing or anything (see Figure 1). 
Figure 1. Extract from VAS: An Opera in Flatland, a novel by Steve Tomasula

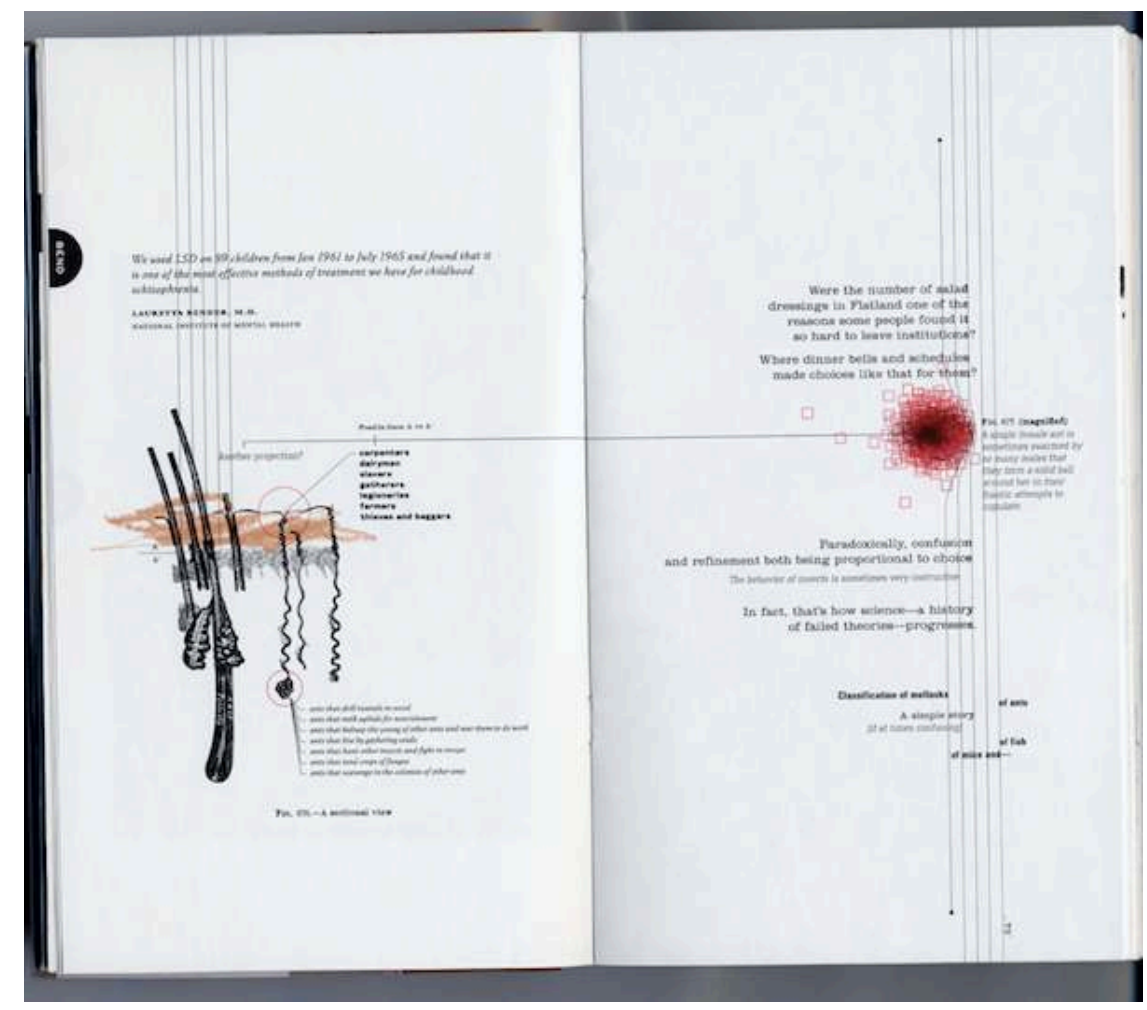

Art and design by Stephen Farrell. University of Chicago Press, 2004. Source: https://www3.nd.edu/ stomasul/VAS_homepage.html

These material gaps cannot be satisfyingly traversed without in each case resolving the predicament in the narrative, and what I find particularly productive, not only in these three fictions but also in other similarly performative experiments, is that this closure means acknowledging my responsibility for the gap. In AVA, I must experience Maso's beginning and end in a given fragment, and once that happens, it becomes obvious that at every instant it was always possible. In VAS, I have to discover myself on the page I am on, as though, when reading, I had been elsewhere, substituting Square's or Tomasula's narration for what I am continuously doing. And in Vanishing Point I need to find the novel's interest in literature's and art's confusions, which is how and where it has always been found. In each case, a discontinuity that appeared written into material reality is dispelled by forms of activity in which I have been engaging for as long as I have been telling and hearing stories. They include recognizing in a later utterance or action the meaning of an earlier one, feeling very differently about the same sentence depending on where it is located, and experiencing all the doubts about an author's words that are raised by the words of a narrator or character. I do not see any other way, following modernism, that the novel as such can be disclosed. The achievements of experimental fiction remain singular, not necessarily in the uniqueness of their form or their self-identical meaning, but in my responsibility being something I alone can acknowledge. At the limit of what one human can impart to or about another, actions are what count. By abstracting what we do from the circumstances in which these actions habitually occur, experimental novelists are not denying that reality exists or that we can know it, but they are reminding us what our actions mean, what does or does not come of them. Wittgenstein famously said that his 
aim in writing was to find a way to stop without doing violence to his own or anyone else's meaning. It is an achievement of that kind that I believe establishes the starting point for knowing what novels are, that gives to any experimental fiction its orienting position.

\section{BIBLIOGRAPHY}

\section{Primary sources}

Austen, Jane. Pride and Prejudice. London: Penguin, 2003. First published 1813.

Barth, John. "Lost in the Funhouse." In Lost in the Funhouse. New York: Anchor Books, 1988. First published 1963.

Barthelme, Donald. "Marie, Marie, Hold on Tight." In Come Back, Doctor Caligari. Boston: Little Brown, 1961.

Beckett, Samuel. Molloy. Trans. Patrick Bowles. In Three Novels. New York: Grove, 1955. First published in French 1947.

Borges, Jorge Luis. “The Library of Babel.” Trans. James E. Irby. In Labyrinths. New York: New Directions, 1962. First published in Spanish 1944.

Cha, Theresa. Dictée. Berkeley: U. California Press, 2001. First published 1982.

Eliot, George. Middlemarch. New York: Norton, 1977. First published 1871-72.

Faulkner, William. The Sound and the Fury. New York: Norton, 1994. First published 1929.

Flaubert, Gustave. Madame Bovary. Trans. Merloyd Lawrence. New York: Houghton Mifflin, 1969. First published 1856-57.

Fowles, John. The French Lieutenant's Woman. London: Vintage books, 1996. First published 1969. Gass, William. Willie Master's Lonesome Wife. New York: Knopf, 1971. First published 1968.

Gass, William. The Tunnel. Normal, IL: Dalkey Archive, 1999. First published 1995.

Joyce, James. Portrait of the Artist as a Young Man. New York: Norton, 2007. First published 1916.

Joyce, James. Ulysses. New York: Random House, 1986. First published 1922.

Joyce, James. Finnegans Wake. New York: Viking, 1976. First published 1939.

Lispector, Clarice. The Passion According to G. H. Trans. Idra Novey. New York: New Directions, 2012. First published in Portuguese 1964.

Markson, David. Vanishing Point. Washington, DC: Shoemaker and Hoard, 2004.

Maso, Carole. AVA. Normal, IL: Dalkey Archive, 2002. First published 1993.

Nabokov, Vladimir. The Annotated Lolita. New York: McGraw-Hill, 1970. Lolita first published 1955. 
Perec, George. Life a User's Manual. Trans. David Bellos. Boston: Godine, 2009. First published in French 1978.

Proust, Marcel. Swann's Way. Trans. C. K. Scott Moncrieff, Terence Kilmartin, D. J. Enright. New York: Modern Library, 2003. First published in French 1913.

Pynchon, Thomas. The Crying of Lot 49. New York: Harper Perennial, 2006. First published 1965. Sorrentino, Gilbert. Mulligan's Stew. Normal, IL: Dalkey Archive, 1996. First published 1979. Stein, Gertrude. Melanctha. In Three Lives. New York: Penguin, 1990. First published 1909. Stein, Gertrude. The Making of Americans. Normal, IL: Dalkey Archive, 2006. First published 1925. Sterne, Laurence. Tristram Shandy. London: Penguin, 2003. First published 1759-67.

Sukenick, Ronald. "The Death of the Novel." In The Death of the Novel and Other Stories. Tallahassee, FL: Fiction Collective 2, 2003. 41-102. First published 1969.

Tomasula, Steve. VAS. Chicago: U. of Chicago Press, 2004. First published 2002.

Woolf, Virginia. “Mr. Bennett and Mrs. Brown.” In A Bloomsbury Group Reader. S. P. Rosenbaum, ed. Cambridge MA: Blackwell, 1993. 233-249. First published 1923.

Woolf, Virginia. To the Lighthouse. Orlando, FL: Harcourt, 1981. First published 1927.

\section{Secondary sources}

Brooks, Cleanth. The Well-Wrought Urn. New York: Harcourt Brace, 1947.

Federman, Raymond, ed. Surfiction: Fiction Now and Tomorrow. Chicago: Swallow Press, 1975.

Fry, Roger. “The Philosophy of Impressionism.” In A Roger Fry Reader. Christopher Reed (ed.). Chicago: U. of Chicago P., 1996a. 12-20.

Fry, Roger. "Post-Impressionism," in A Roger Fry Reader. Christopher Reed, ed. Chicago: U. of Chicago P., 1996b. 99-110.

Shklovsky, Victor. "Sterne's Tristram Shandy: Stylistic Commentary.” Trans. by Lee T. Lemon and Marion J. Reis. Russian Formalist Criticism: Four Essays. Lincoln: U. of Nebraska P., 1965. 27-57.

Wittgenstein, Ludwig. Philosophical Investigations. Trans. by G. E. M. Anscombe, P. M. S. Hacker and Joachim Schulte, $4^{\text {th }}$ ed. Revised. Malden MA: Blackwell, 2009. First published 1953.

\section{ABSTRACTS}

The essay interprets experimental novels as attempts to determine what a novel is, rather than as formal innovations or challenges to realist conventions. A consequence of such an interpretation is that the stakes of aesthetic discourse are raised unusually high, making an issue of the very concept. For modernist novelists like Virginia Woolf, these raised stakes mean that knowledge of what a novel is, although radically democratic, poses a problem similar to the epistemology of other minds, that is, a problem of subjective isolation, of solipsism. In such a context, understanding the history of novelistic practice subsequent to modernist experimentation requires acknowledging this potential of aesthetic knowledge to individuate readers and writers. That assigning an orienting position to specific novels or novelists today seems arbitrary, if not hegemonic, does not result from anything about the political and ethical conditions of aesthetic practice that modernist novelists did not themselves know. On the 
contrary, it results from the success of their experiments, from the aesthetic achievements of writers such as Woolf. What their conceptually transforming ambitions have made manifest is that, for those familiar with novels generally, questioning what passes for literary fiction today is not a matter of lacking knowledge, or none that even the most widely recognized novelist or critic possesses. This situation resembles the one addressed by Wittgenstein in the "private language" section of Philosophical Investigations. The specific resemblance is that, although concepts of either aesthetics or feelings, once questioned, can prove difficult to justify or explain, their difficulty presupposes no lack of knowledge of aesthetics or feelings. On the contrary, Wittgenstein suggests that this "picture" of a lack is itself part of the difficulty. In his later philosophy, conceptual problems seem to arise in much the way that novelistic problems in the post-WWII period seemed to have arisen, specifically, as a result of language users questioning the conceptual conditions of their own practice. For experimental novelists of the sixties and seventies, writing a novel seemed as ambitious an undertaking as for their modernist forerunners, but a question arose for them about what such ambition entailed. Had the modernists succeeded in laying bare the forms immanent in all classic novels, forms on which the significance of stories at any time depended, or had they demonstrated the limits of such forms? The difference was that between acknowledging what a novel is and rendering the concept unknowable, but both the acknowledgment and its skeptical denial seemed to follow from the same question. Wittgenstein's solution to problems of this kind in Philosophical Investigations is to write such that hearing what the question asks means recognizing our responsibility for the difference. The accepted term among literary critics for writing of this kind is "performative." It differs from representation in the way that an act of narrating differs from a narrative of action. The essay concludes by showing through brief readings of novels by David Markson, Carole Maso, and Steve Tomasula, that radically experimental fictions can go beyond self-questioning, performing an act of acknowledging what narration is.

Cet article envisage le roman expérimental comme une tentative pour déterminer ce qu'est le roman, plutôt que comme un ensemble d'innovations formelles ou de remises en question des conventions réalistes. L'une des conséquences d'une telle interprétation est que les enjeux du discours esthétique sont placés très hauts, et remettent en question le concept lui-même. Pour une écrivaine moderniste comme Virginial Woolf, cela veut dire que le savoir sur le roman, bien que radicalement démocratique, pose un problème similaire à l'épistémologie d'autres esprits, c'etsà-dire un problème d'isolement subjectif, ou de solipsisme. Dans un tel contexte, comprendre l'histoire de la pratique de l'écriture romanesque venant après l'expérimentation moderniste requiert une reconnaissance de ce potentiel d'un savoir esthétique possédé par les lecteurs et écrivains individuels. Que le fait d'assigner une position orientante à des romans ou des romanciers spécifiques aujourd'hui puisse sembler arbitraire, si ce n'est hégémonique, ne résulte pas de quoi que ce soit qui concerne les conditions politiques et éthiques de la pratique esthétique que les romanciers modernistes ne connaissaient pas eux-même. Au contraire, cela résulte du succès de leurs expérimentations, des réussites esthétiques d'écrivains tels que Woolf. Ce que leur ambition de transformer les choses conceptuellement a rendu manifest est que, pour ceux qui sont familiers avec les romans en général, remettre en question ce qui est considéré comme de la fiction littéraire aujourd'hui n'est pas un problème d'un manque de savoir, ni d'aucun savoir que le romancier ou critique le plus largement reconnu ne possède. Cette situation ressemble à celle qu'analyse Wittgenstein dans la section des Investigations Philosophiques intitulée «le langage privé ». Ce qui est particulièrement ressemblant est que bien que les concepts aesthétiques ou bien se référant aux sentiments, une fois remis en question, puissent s'avérer difficiles à justifier ou à expliquer, leur difficulté ne présuppose pas une ignorance de ce que sont l'esthétique ou les sentiments. Au contraire, Witgenstein suggère que cette "image " d'un manque en elle-même fait partie de la difficulté. Dans sa philosophie 
ultérieure, les problèmes conceptuels semblent surgir de la même façon que les problèmes du roman dans la période de l'après deuxième guerre mondiale, plus précisément comme le résultat $\mathrm{du}$ fait que les utilisateurs de langage remettent en question les conditions conceptuelles de leur propre pratique. Pour les romanciers expérimentaux des années 60 et 70, écrire un roman paraissait être une entreprise aussi ambitieuse que pour leur prédécesseurs modernistes, mais une question s'est posée à eux à propos de ce que cette ambition signifiait. Est-ce que les modernistes avaient réussi à mettre à nu les formes immanentes à tous les romans classiques, des formes dont dépendaient la signification des histoires de tout temps, ou bien avaient-ils démontré les limites de telles formes ? La différence revient à celle existant entre le fait de reconnaître ce qu'est un roman et le fait de rendre le concept inconnaissable, mais la reconnaissance tout comme sa négation sceptique semblent être produits par la même question. La solution apportée par Witgenstein aux problèmes de ce genre dans les Investigations philosophiques est d'écrire de telle manière qu'entendre les présupposés de cette question veut dire reconnaître notre responsabilité dans l'établissement de cette différence. Le terme habituellement utilisé par les critiques littéraires pour cette manière d'écrire est «performative ». Elle diffère de la représentation au sens où l'action de faire récit diffère du récit d'action. L'article conclut, à travers de courtes analyses de romans écrits par David Markson, Carole Maso et Steve Tomasula, sur l'idée que des fictions radicalement expérimentales peuvent aller au-delà de la remise en question de la forme propre pour produire de manière performative un acte de reconnaissance de ce qu'est le récit.

\section{INDEX}

Mots-clés: fiction expérimentale, roman moderniste, Wittgenstein Ludwig, langage privé, métafiction, autonomie, fiction performative, Markson David, Maso Carole, Tomasula Steve Keywords: experimental fiction, modernist novel, Wittgenstein Ludwig, private language, metafiction, autonomy, performative writing, Markson David, Maso Carole, Tomasula Steve

\section{AUTHOR}

\section{RALPH M. BERRY}

R. M. Berry is author of the novels Frank (2006), an "unwriting" of Mary Shelley's Frankenstein, and Leonardo's Horse, a New York Times “notable book" of 1998, as well as two collections of short fiction, Dictionary of Modern Anguish (2000), described by the Buffalo News as "inspired [...] by the spirit of Ludwig Wittgenstein," and Plane Geometry and Other Affairs of the Heart, winner of the 1985 Fiction Collective Prize. He edited the fiction anthology Forms at War: FC2 1999-2009and, with Jeffrey DiLeo, the critical anthology Fiction's Present: Situating Contemporary Narrative Innovation (2007). His essays on experimental fiction, Wittgenstein's philosophy, and Stanley Cavell have appeared in such journals as New Literary History, Philosophy and Literature, Symploké, Narrative, and Soundings, and in such volumes as the Oxford Handbook of Philosophy and Literature (2009), Stanley Cavell and Literary Studies (2011), and Ordinary Language Criticism: Literary Thinking After Cavell After Wittgenstein (2003). He is emeritus professor and former chair of English at Florida State University and the former director of the independent literary publisher FC2. Having retired from teaching at the end of 2016, he and his wife, Ruth Fleming, now live in Atlanta, GA. Contact: rberry[at]fsu.edu 